\title{
SYNTHESIS, CHARACTERIZATION, AND ANTIBACTERIAL ACTIVITIES OF CHROMIUM OXIDE NANOPARTICLES AGAINST KLEBSIELLA PNEUMONIAE
}

\author{
POONAM SANGWAN ${ }^{*}$, HARISH KUMAR ${ }^{2}$ \\ ${ }^{1}$ Department of Chemistry, GDC Memorial College, Bahal, Haryana, India. ${ }^{2}$ Department of Chemistry, Chaudhary Devilal University, Sirsa, \\ Haryana, India. Email: poonam.sangwan35@gmail.com
}

Received: 14 September 2016, Revised and Accepted: 27 October 2016

\section{ABSTRACT}

Objective: This paper consists of synthesis of chromium oxide $\left(\mathrm{Cr}_{2} \mathrm{O}_{3}\right)$ nanoparticles by sol-gel technique, their characterization and investigation of antibacterial activity of these nanoparticles against pathogenic bacteria by measuring zone of inhibition, colony forming units, and optical density (OD) on solid agar media as well as in liquid medium.

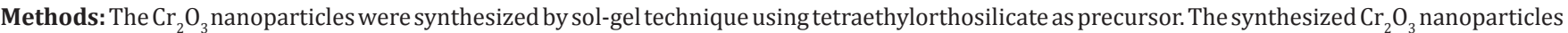
were characterized by X-ray diffraction (XRD), Fourier-transform infrared spectroscopy, ultraviolet-visible spectroscopy, and transmission electron microscopy (TEM) techniques. The antibacterial effect of these $\mathrm{Cr}_{2} \mathrm{O}_{3}$ nanoparticles against Klebsiella pneumoniae was investigated both on the solid agar plates and in liquid medium supplemented with different concentrations of $\mathrm{Cr}_{2} \mathrm{O}_{3}$ nanoparticles. The antibacterial activity of $\mathrm{Cr} \mathrm{O}_{3}$ nanoparticles was also compared with the antibacterial activities of the standard antibiotics such as ampicillin, chloramphenicol, penicillin G, streptomycin, sulphatriad, and tetracycline which were taken in the form of hexa discs.

Results: Average particle size of the $\mathrm{Cr}_{2} \mathrm{O}_{3}$ nanoparticles was found to be $24.0 \mathrm{~nm}$. It was observed that $K$. pneumoniae is resistant to the penicillin $\mathrm{G}$ and ampicillin, but $\mathrm{Cr}_{2} \mathrm{O}_{3}$ nanoparticles show good antibacterial property. The minimum inhibitory concentration of $\mathrm{Cr}_{2} \mathrm{O}_{3}$ for $\mathrm{K}$. pneumoniae is $2.5 \mathrm{mg} / \mathrm{ml}$. The bacterial growth was monitored by measuring zone of Inhibition, colony formation unit, and OD method.

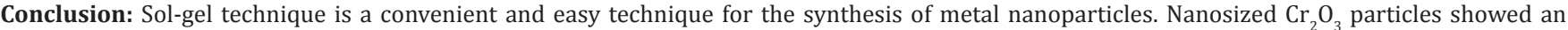
effective antibacterial activity against $K$. pneumoniae. Therefore, $\mathrm{Cr}_{2} \mathrm{O}_{3}$ nanoparticles due to its low manufacturing cost and high effectiveness in antimicrobial properties may find wide applications in various industries to address safety issues.

Keywords: Klebsiella pneumoniae, Chromium oxide nanoparticles, X-ray diffraction, Transmission electron microscopy.

(c) 2017 The Authors. Published by Innovare Academic Sciences Pvt Ltd. This is an open access article under the CC BY license (http://creativecommons. org/licenses/by/4. 0/) DOI: http://dx.doi.org/10.22159/ajpcr.2017.v10i2.15189

\section{INTRODUCTION}

Transition metal oxide nanoparticles represent a broad class of materials that have been researched extensively due to their interesting catalytic, electronic, magnetic, and medicinal properties. The nanobiotechnology studies have focused on the medical applications of nanoparticles for treatments and antibacterial effect. Recently, chromium oxides $\left(\mathrm{Cr}_{2} \mathrm{O}_{3}\right)$ have attracted much attention due to their importance in science as well as in technology. Chromia $\left(\mathrm{Cr}_{2} \mathrm{O}_{3}\right)$, possess specific applied applications such as in high-temperature resistant materials [1], corrosion resistant materials [2], liquid crystal displays [3], green pigment [4], heterogeneous catalysts $[5,6]$, coating materials $[7,8]$, and so on. The intrinsic properties of inorganic materials are mainly determined by their composition, structure, crystallinity, size and morphology; great efforts have been devoted to the investigation of different $\mathrm{Cr}_{2} \mathrm{O}_{3}$ materials synthesis [9-11].

$\mathrm{Cr}_{2} \mathrm{O}_{3}$ nanoparticles have been synthesized by different methods such as hydrothermal [12,13] solid thermal decomposition [14], sol-gel [15], combustion [16], precipitation-gelation [17], microwave irradiation [3,18], inverse-microemulsion [19], oxidation of chromium in oxygen [20], and precipitation [21] methods. Negahdary et al. [22] synthesized $\mathrm{Cr}_{2} \mathrm{O}_{3}$ nanoparticles with chemical methods. Characterization of nanoparticles studied with ultraviolet (UV)-visible spectrophotometer, X-ray diffractometer, and transmission electron microscopy (TEM) microscope. Ramesh et al. [23] synthesized $\mathrm{Cr}_{2} \mathrm{O}_{3}$ nanoparticles by reduction of potassium dichromate solution with Arachis hypogaea leaf extract. The antibacterial effect of $\mathrm{Cr}_{2} \mathrm{O}_{3}$ nanoparticles against Escherichia coli was investigated as a model for gram-negative bacteria. Khatoon et al. [24] reported the internalization of $\mathrm{Cr}_{2} \mathrm{O}_{3}$ nanoparticles in Escherichia coli cells by flow cytometry using light scattering method. El-Ajaily et al. [25] reported the antibacterial activity of $\mathrm{Cr}$ (VI) and $\mathrm{Cr}$ (III) complexes against $P$. aeruginosa bacteria. Singh et al. [26] reported viability of an environmentally relevant bacterium, E. coli exposed to varying concentrations of $\mathrm{Cr}_{2} \mathrm{O}_{3}$ nanoparticles was evaluated propidium mono-azide assisted quantitative-polymerase chain reaction. Rakesh et al. [27] synthesized the $\mathrm{Cr}_{2} \mathrm{O}_{3}$ nanoparticles by reduction of potassium dichromate solution with Mukia maderaspatana plant extract. The resulting $\mathrm{Cr}_{2} \mathrm{O}_{3}$ nanoparticles were characterized by X-ray diffraction (XRD), SEM, UVvisible absorption and Fourier-transform infrared (FTIR) spectroscopy. The antibacterial effect of $\mathrm{Cr}_{2} \mathrm{O}_{3}$ nanoparticles against $E$. coli was investigated. Khalil [28] investigated the antibacterial activity of chromium nanoparticles on two phytopathogenic bacteria, namely, Erwinia carotovora and Pseudomonas fluorescens. Therefore, the transition metal nanoparticles have been researched widely because of their good antimicrobial activity [29,30].

\section{METHODS}

Materials

Klebsiella pneumoniae (MTCC 3384) was obtained from microbial type culture collection (MTCC), Institute of Microbial Technology, Chandigarh. All other chemicals used in the experiment were of AR grade and obtained from standard chemical sources. 
Synthesis of $\mathrm{Cr}_{2} \mathbf{O}_{3}$ nanoparticles

$\mathrm{Cr}_{2} \mathrm{O}_{3}$ nanoparticles were synthesized using sol-gel method. The procedure uses chromium trioxide solution of $\mathrm{pH} 1-2$, ethanol and tetraethylorthosilicate (TEOS) as the precursor material. The $\mathrm{Cr}_{2} \mathrm{O}_{3}$ nanoparticles were prepared by mixing chromium trioxide solution drop by drop into the flask containing 1:4 TEOS and ethanol solution with continuous stirring. The resulting solution was heated at $70.0^{\circ} \mathrm{C}$ with continuous stirring in a closed container for $6.0 \mathrm{hrs}$. The resulting solution was then kept in the oven at $100.0^{\circ} \mathrm{C}$ for $10-15$ days, and after that, the particles were kept in muffle furnace at $400.0^{\circ} \mathrm{C}$ for $4.0 \mathrm{hrs}$. Blackish green $\mathrm{Cr}_{2} \mathrm{O}_{3}$ nanoparticles were obtained.

\section{Characterization techniques}

The size, structure, morphology and magnetic properties of as-prepared metal nanoparticles were characterized by FTIR (shimadzu corp-02014) in the wavelength range 400-4000/cm, UV-visible spectroscopy (Shimadzu 1800) in the wavelength range $200-1000 / \mathrm{cm}$, XRD (Rikagu mini-2 using Cu $\alpha 1, \lambda=0.15406 \mathrm{~nm}$ radiations), and TEM (FEI-Philips, Morgagni 286D with magnification up to 2,80,000x, Acc. Voltage: $100 \mathrm{Kv}$ ).

\section{Antibacterial study}

The antibacterial activity of $\mathrm{Cr}_{2} \mathrm{O}_{3}$ nanoparticles against $K$. pneumoniae was tested by measuring zone of inhibition (ZOI), evaluating colony forming unit (CFU) on solid medium, and by measuring the optical density (OD) of culture solution. The zone of inhibition (ZOI) was measured by agar well-diffusion method. Nutrient broth/agar $0.1 \mathrm{~g}$ beef, 0.2 g yeast extract, $0.5 \mathrm{~g}$ peptone, $0.5 \mathrm{~g} \mathrm{NaCl}$ dissolved in $100 \mathrm{ml}$ of double distilled water) was used to cultivate bacteria. The media was autoclaved and cooled. The media was poured in the previously sterilized petri plates and kept for 30 minutes for solidification. After 30 minutes, the plates were left overnight at room temperature to check for any contamination to appear. The bacterial test organism $K$. pneumoniae were grown in nutrient broth at $37^{\circ} \mathrm{C}$ for $24.0 \mathrm{hrs}$. A $100 \mu \mathrm{l}$ of the fresh overnight nutrient broth culture was spread onto solidified nutrient agar plates. Wells of $8.0 \mathrm{~mm}$ diameter were prepared with the help of a sterilized stainless steel cork borer. Using a micropipette, different concentrations of the $\mathrm{Cr}_{2} \mathrm{O}_{3}$ nanoparticles solution $(2.5,3.0,3.25,3.5,3.75,4.0,6.0,8.0,10.0,12.0 \mathrm{mg} / \mathrm{ml})$ was poured into each well on the plates. Various antibiotics in the form of hexa discs were used as a positive control for bacteria to compare the inhibition of bacterial growth with $\mathrm{Cr}_{2} \mathrm{O}_{3}$ nanoparticles. The plates containing bacteria solutions of nanoparticles and antibiotic discs were incubated at $37.0^{\circ} \mathrm{C}$ for $24.0 \mathrm{hrs}$. After $24.0 \mathrm{hrs}$ of incubation, the different level of zone of Inhibition produced by $\mathrm{Cr}_{2} \mathrm{O}_{3}$ nanoparticles against K. pneumoniae was measured in $\mathrm{mm}$.

\section{CFU and OD measurement}

K. pneumoniae was used for colony forming units (CFU) measurement on the solid medium plate. Serial dilutions of the broth culture were prepared. $0.1 \mathrm{ml}$ of $10^{-6}$ dilution of the bacterial culture was tested with different concentration $(1.0,2.0,3.0 \mathrm{mg} / \mathrm{ml})$ of $\mathrm{Cr}_{2} \mathrm{O}_{3}$ nanoparticles. After incubation at $37.0^{\circ} \mathrm{C}$, the number of $\mathrm{CFU}$ was counted. The growth behavior of the $K$. pneumoniae was also investigated by measuring OD through the administration of the $\mathrm{Cr}_{2} \mathrm{O}_{3}$ nanoparticles at different concentrations into the dilute solution of the broth culture.

\section{RESULTS AND DISCUSSION}

The average particle size was calculated from XRD data using Scherrer's equation. Particle morphology of the sample was investigated by a TEM. FTIR spectroscopy was performed to know the synthesis condition, and UV-visible spectroscopy was carried out for the optical study of metal nanoparticles. Fig. 1 shows XRD pattern of the $\mathrm{Cr}_{2} \mathrm{O}_{3}$ nanoparticles. The inspection of XRD pattern revealed that $\mathrm{Cr}_{2} \mathrm{O}_{3}$ thus formed is of rhombohedral phase (JCPDS no. 38-1479 with $\mathrm{a}=4.9587$ $\mathrm{A}^{\circ} \mathrm{C}=13.594 \mathrm{~A}^{\circ}$ ). The major peaks at $2 \theta$ values of $24.62,33.8,36.4$, $41.8,50.32,55.16,63.6$, and 65.32 are indexed as (012), (104), (110), (113), (024), (116), (214), (300), respectively. Average particle size of the $\mathrm{Cr}_{2} \mathrm{O}_{3}$ nanoparticles was found to be $24.0 \mathrm{~nm}$ using Scherrer's formula $d=K \lambda / \beta \operatorname{Cos} \theta$ where the constant $K$ is taken to be $0.94, \lambda$ is the wavelength of X-ray and $\beta$, and $\theta$ are the full width at half maximum and Braggs angle, respectively.

Fig. 2 shows the TEM image of the $\mathrm{Cr}_{2} \mathrm{O}_{3}$ nanoparticles. The microstructural characterization studies were conducted to determine the size of nanoparticles and examine the homogeneity and size distribution. The particles were observed to be almost spherical. It can be seen from the Fig. 2 that there is a uniform distribution of the particle with mean particle size $21.36 \mathrm{~nm}$ which is in close agreement with the XRD result.

Fig. 3 shows FTIR spectra of $\mathrm{Cr}_{2} \mathrm{O}_{3}$ nanoparticles synthesized by sol-gel technique. FTIR spectroscopy was carried out to ascertain the purity and nature of metal or metal oxide nanoparticles. The band between 3200 and $3400 / \mathrm{cm}$ and $1622 / \mathrm{cm}$ are due to the $-\mathrm{OH}$ stretching and bending vibrations of adsorbed water molecule on the sample, band at $2929 / \mathrm{cm}$ may be due to $-\mathrm{CH}_{3}$ stretching vibrations $1072 / \mathrm{cm}$ is due to Cr-O-Cr vibrations $952 / \mathrm{cm}$ and $902 / \mathrm{cm}$ are assigned to $\mathrm{Cr}=0$ vibrations. The two peaks at 550 and $617 / \mathrm{cm}$ are assigned to $\mathrm{Cr}-\mathrm{O}$ str. modes are evidence for the presence of crystalline $\mathrm{Cr}_{2} \mathrm{O}_{3}$ nanoparticles [31].

The optical characterization of the sample was recorded on UV-visible absorption spectrophotometer. Fig. 4 shows UV-visible spectra of $\mathrm{Cr}_{2} \mathrm{O}_{3}$ nanoparticles as a function of wavelength. The UV-visible absorption spectroscopy of $\mathrm{Cr}_{2} \mathrm{O}_{3}$ nanoparticles shows an absorption peak at about 351.2 and $255.1 \mathrm{~nm}$. The band energy gap was found to be $4.19 \mathrm{eV}$.

Fig. 5 shows the zone of inhibition of bacterial growth produced by different concentration of $\mathrm{Cr}_{2} \mathrm{O}_{3}$ nanoparticles on agar plates. The minimum inhibitory concentration (MIC) of $\mathrm{Cr}_{2} \mathrm{O}_{3}$ nanoparticles for $K$. pneumoniae was observed at $2.5 \mathrm{mg} / \mathrm{ml}$. Table 1 shows the average zone of inhibition produced at different concentrations of the synthesized $\mathrm{Cr}_{2} \mathrm{O}_{3}$ nanoparticles, and these results reveal the strong efficiency of these $\mathrm{Cr}_{2} \mathrm{O}_{3}$ nanoparticles to inhibit the bacterial growth.

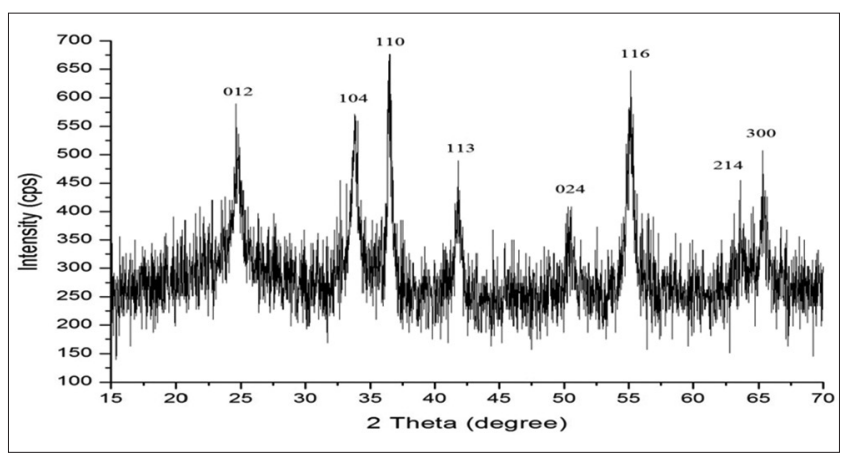

Fig. 1: X-ray diffraction pattern of chromium oxide nanoparticles

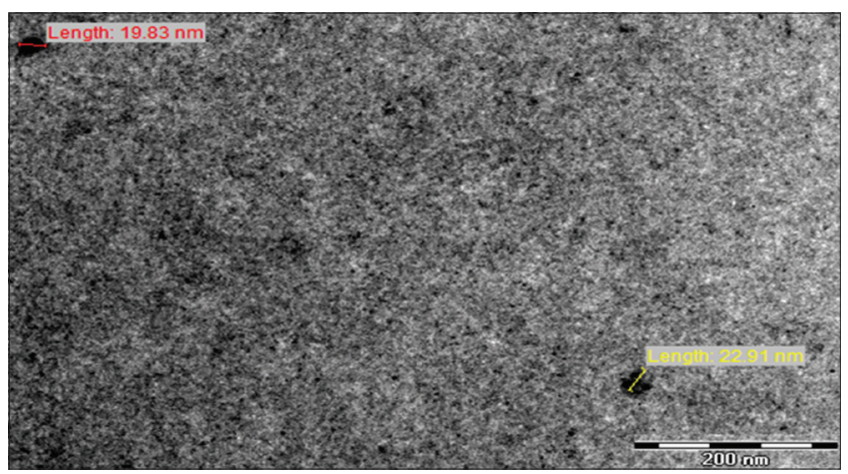

Fig. 2: Transmission electron microscopy image of chromium oxide nanoparticles 
The zone of inhibition increases gradually as the concentration of $\mathrm{Cr}_{2} \mathrm{O}_{3}$ nanoparticles increases. Results clearly demonstrate that synthesized $\mathrm{Cr}_{2} \mathrm{O}_{3}$ nanoparticles act as promising antimicrobial agent.

Fig. 6 shows the zone of inhibition produced by different antibiotics such as ampicillin (10 mcg), chloramphenicol $(25 \mathrm{mcg})$, penicillin G (1 unit), streptomycin (10 mcg), sulphatriad (300 mcg), and tetracycline (25 mcg) which are taken in the form of hexa discs. It was found that K. pneumoniae is resistant to the penicillin $\mathrm{G}$ and ampicillin.

Fig. 7 shows the colony forming unit measurement on the solid medium plate. The serial dilutions of the broth culture were prepared. $0.1 \mathrm{ml}$ of $10^{-6}$ dilution of the bacterial culture were spread on the plate (a), plates (b), (c) and (d) consists of $0.1 \mathrm{ml}$ of diluted broth with different concentrations $(1.0 \mathrm{mg} / \mathrm{ml}, 2.0 \mathrm{mg} / \mathrm{ml}, 3.0 \mathrm{mg} / \mathrm{ml})$ of $\mathrm{Cr}_{2} \mathrm{O}_{3}$ nanoparticles. These plates were incubated at $37.0^{\circ} \mathrm{C}$ for $24.0 \mathrm{hrs}$. After $24.0 \mathrm{hrs}$, the numbers of CFU were counted. There were 185 colonies were counted on plate (a) and the number of CFU decreases as the concentration of metal nanoparticles increases. This shows that the $\mathrm{Cr}_{2} \mathrm{O}_{3}$ exhibited good antibacterial property.

Aqueous dispersion of these nanoparticles at desired concentrations was made. The $50 \mathrm{ml}$ of diluted bacterial cells were taken in different flasks. The solutions were taken in real life situations. Shaking provided

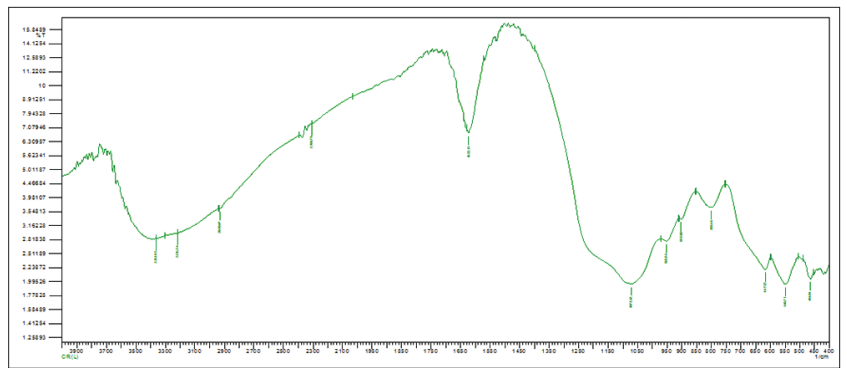

Fig. 3: Fourier-transform infrared spectra of chromium oxide nanoparticles

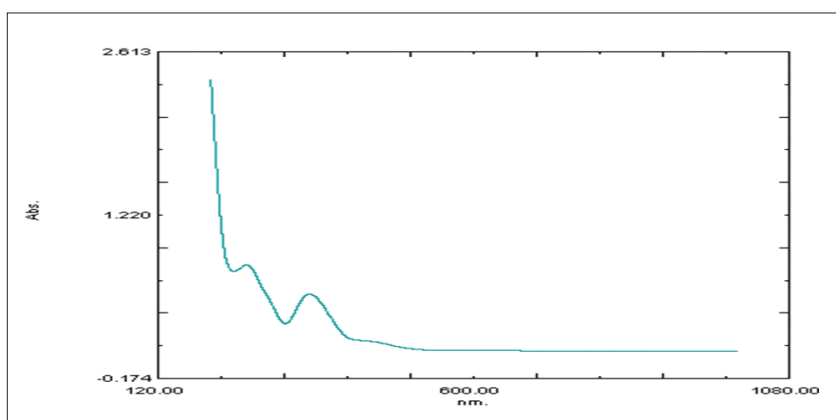

Fig. 4: Ultraviolet-visible absorption spectra of chromium oxide nanoparticles
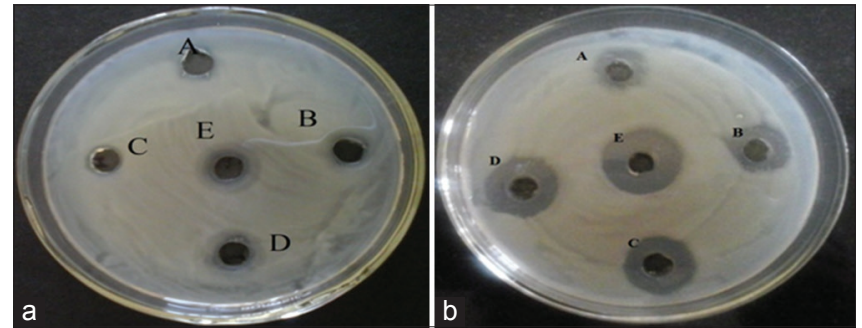

Fig. 5: Zone of inhibition produced by different concentrations of chromium oxide nanoparticles. (a) $(2.5 \mathrm{mg} / \mathrm{ml}$,

$3.0 \mathrm{mg} / \mathrm{ml}, 3.25 \mathrm{mg} / \mathrm{ml}, 3.5 \mathrm{mg} / \mathrm{ml}, 3.75 \mathrm{mg} / \mathrm{ml})$, (b) $(4.0 \mathrm{mg} / \mathrm{ml}$, $6.0 \mathrm{mg} / \mathrm{ml}, 8.0 \mathrm{mg} / \mathrm{ml}, 10.0 \mathrm{mg} / \mathrm{ml}, 12.0 \mathrm{mg} / \mathrm{ml}$ ) against Klebsiella pneumoniae bacteria aeration and homogeneity. Control flask containing all the initial reaction components except the $\mathrm{Cr}_{2} \mathrm{O}_{3}$ nanoparticles showed no antibacterial activity. $\mathrm{Cr}_{2} \mathrm{O}_{3}$ nanoparticles were added in the solution at the beginning of bacterial cell growth. Optical densities as a function of time measured periodically up to $24.0 \mathrm{~h}$ of control and solutions containing different concentrations of $\mathrm{Cr}_{2} \mathrm{O}_{3}$ nanoparticles as shown in Fig. 8 and it is observed that as the concentration of $\mathrm{Cr}_{2} \mathrm{O}_{3}$ nanoparticles increases, the growth decreases.

\section{CONCLUSION}

$\mathrm{Cr}_{2} \mathrm{O}_{3}$ nanoparticles of average particle size $24.0 \mathrm{~nm}$ were synthesized using Sol-gel method. Antibacterial study of $\mathrm{Cr}_{2} \mathrm{O}_{3}$ nanoparticles was investigated against $K$. pneumoniae by using zone of inhibition, $\mathrm{CFU}$ measurement, and OD methods. The zone of inhibition shown by the $\mathrm{Cr}_{2} \mathrm{O}_{3}$ nanoparticles against $K$. pneumoniae was compared with well-known antibiotics. It is observed that $K$. pneumoniae is resistant to the penicillin $\mathrm{G}$ and ampicillin, but $\mathrm{Cr}_{2} \mathrm{O}_{3}$ nanoparticles show good antibacterial property. The $\mathrm{MIC}$ of $\mathrm{Cr}_{2} \mathrm{O}_{3}$ for $K$. pneumoniae is $2.5 \mathrm{mg} / \mathrm{ml}$. The zone of inhibition, CFU estimation and OD curves shows that the bacterial growth reduces significantly with the increase in the concentration of $\mathrm{Cr}_{2} \mathrm{O}_{3}$ nanoparticles. The results obtained from zone of inhibition, CFU and OD curves were in close agreement with each other. Therefore, it is concluded that the $\mathrm{Cr}_{2} \mathrm{O}_{3}$ nanoparticles are easy to synthesize and possess good antibacterial activities.

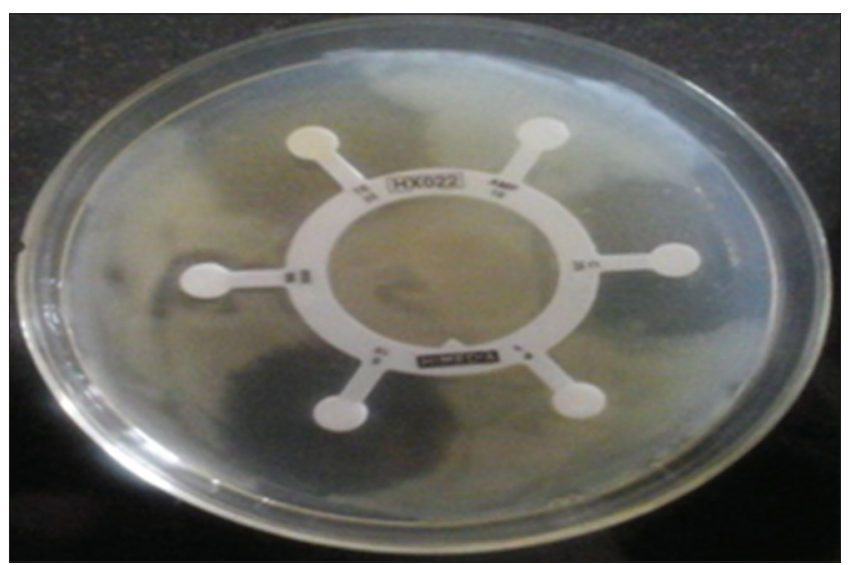

Fig. 6: Zone of inhibition produced by different antibiotics (ampicillin [10 mcg], chloramphenicol [25 mcg], penicillin G [1 unit], streptomycin [10 mcg], sulphatriad [300 mcg], tetracycline [25 mcg]) against Klebsiella pneumoniae
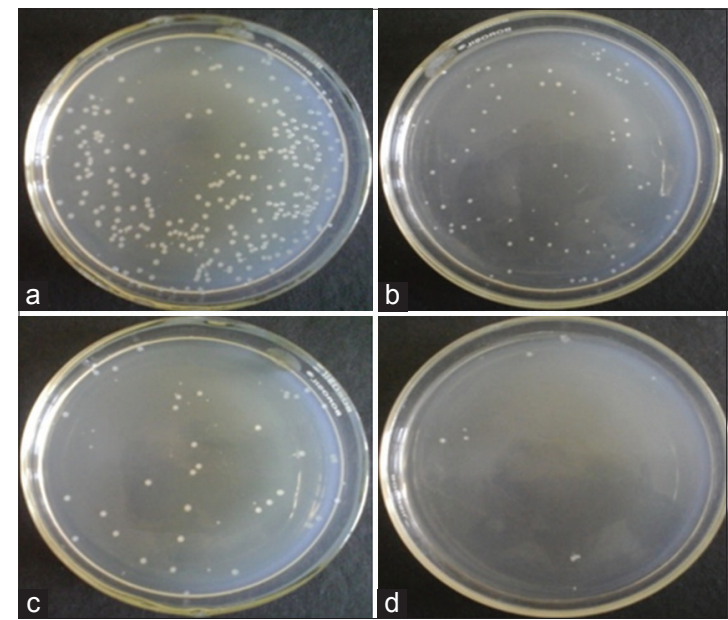

Fig. 7: Agar plates showing CFU count at different concentrations of chromium oxide nanoparticles against Klebsiella pneumonia.

(a) $0.1 \mathrm{ml}$ of diluted broth, (b) Diluted broth $+1.0 \mathrm{mg} \mathrm{Cr} \mathrm{NP}$, (c) diluted broth $+2.0 \mathrm{mg} \mathrm{Cr} \mathrm{NP}$, (d) diluted broth $+3.0 \mathrm{mg} \mathrm{Cr} \mathrm{NP}$ 


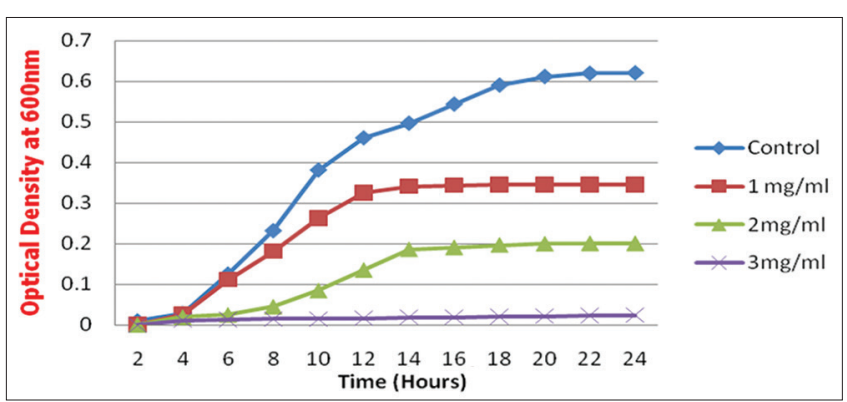

Fig. 8: Effect of chromium oxide nanoparticles on the growth of Klebsiella pneumoniae

Table 1: Result of agar well-diffusion method

\begin{tabular}{ll}
\hline $\begin{array}{l}\text { Concentration of } \mathrm{Cr}_{2} \mathbf{O}_{3} \\
\text { nanoparticles } \mathbf{~} \mathbf{m g l}\end{array}$ & $\begin{array}{l}\text { Average zone of } \\
\text { inhibition } \mathbf{( m m})\end{array}$ \\
\hline 2.5 & $8.7 \pm 0.58$ \\
3.0 & $9.3 \pm 0.58$ \\
3.25 & $9.7 \pm 1.15$ \\
3.50 & $10.0 \pm 0.0$ \\
3.75 & $10.2 \pm 0.76$ \\
4.0 & $11.8 \pm 0.6$ \\
6.0 & $14.5 \pm 0.5$ \\
8.0 & $16.6 \pm 0.0$ \\
10.0 & $17.3 \pm 0.6$ \\
12.0 & $19.6 \pm 0.6$ \\
\hline
\end{tabular}

\section{ACKNOWLEDGMENTS}

This work was supported by the Department of Biotechnology, Chaudhary Devi Lal University, Sirsa and financial support was provided by University Grant Commission (UGC), New Delhi.

\section{REFERENCES}

1. Yang $\mathrm{X}$, Peng $\mathrm{X}, \mathrm{Xu} \mathrm{C}$, Wang F. Electrochemical assembly of Ni-xCr-yAL nanocomposites with excellent high-temperature oxidation resistance. J Electrochem Soc 2009;156(7):167-75.

2. Li CL, Zhao HX, Takahashi T, Matsumura M. Improvement of corrosion resistance of materials coated with a $\mathrm{Cr}_{2} \mathrm{O}_{3} / \mathrm{NiCr}$ delayer using a sealing treatment. Mater Sci Eng A 2001;308(1-2):268-76.

3. Al-Saadi TM, Hameed NA. Synthesis and structural characterization of $\mathrm{Cr}_{2} \mathrm{O}_{3}$ nanoparticles prepared by using $\mathrm{Cr}\left(\mathrm{NO}_{3}\right)_{3} .9 \mathrm{H}_{2} \mathrm{O}$ and triethanolamine under microwave irradiation. Adv Phys Theor Appl 2015;44:139-48.

4. Li P, Xu HB, Zhang Y, Li ZH, Zheng SL, Bai YL. The effects of Al and $\mathrm{Ba}$ on the colour performance of chromic oxide green pigment. Dyes Pigm 2009;80:287-91.

5. Rao TV, Yang Y, Sayari A. Ethane dehydrogenation over pore-expanded mesoporous silica supported chromium oxide: 1. Catalysts preparation and characterization. J Mol Catal A Chem 2009;301(1-2):152-8.

6. Wanga G, Zhang L, Deng J, Dai H, He H, Tong C. Preparation, characterization and catalytic activity of chromia supported on SBA-15 for the oxidative dehydrogenation of isobutene. Appl Catal A 2009;355(1-2):192-201.

7. Pang X, Gao K, Luo F, Emirov Y, Levin AA, Volinsky AA. Investigation of microstructure and mechanical properties of multi-layer $\mathrm{Cr} / \mathrm{Cr}_{2} \mathrm{O}_{3}$ coatings. Thin Solid Films 2009;517(6):1922-7.

8. Hou X, Choy KL. Synthesis of $\mathrm{Cr}_{2} \mathrm{O}_{3}$-based nanocomposite coatings with incorporation of inorganic fullerene-like nanoparticles. Thin Solid Films 2008;516(23):8620-4.

9. Abecassis-Wolfovich M, Rotter H, Landau MV, Korin E, Erenburg AI,
Mogilyansky D, et al. Texture of chromia aerogels and structure of their nanocrystals. Stud Surf Sci Catal 2003;146:247-50.

10. Bai YL, Xu HB, Zhang Y, Li ZH. Reductive conversion of hexavalent chromium in the preparation of ultra-fine chromia powder. J Phys Chem Solids 2006;67:2589-95.

11. Landau MV, Shter GE, Titelman L, Gelman V, Rotter H, Grader GS, et al. Alumina foam coated with nanostructured chromia aerogel: Efficient catalytic material for complete combustion of chlorinated VOC. Ind Eng Chem Res 2006;45(22):7462.

12. Pei Z, Xu H, Zhang Y. Preparation of $\mathrm{Cr}_{2} \mathrm{O}_{3}$ nanoparticles via $\mathrm{C}_{2} \mathrm{H}_{5} \mathrm{OH}$ hydrothermal reduction. J Alloys Compd 2009;468(1-2):5-8.

13. Sheng L, Feng-Li L, Shao-Min Z, Peng W, Ke C, Zu-Liang D. Highly sensitive room-temperature gas sensors based on hydrothermal synthesis of $\mathrm{Cr}_{2} \mathrm{O}_{3}$ hollow nanospheres. Chin Phys B 2009;18:3985-9.

14. Li LI, Zhu Z, Yao X, Lu G, Yan Z. Synthesis and characterization of chromium oxide nanocrystals via solid thermal decomposition at low temperature. Microporous Mesoporous Mater 2008;112(1-3):621-6.

15. El-Sheikh SM, Mohamed RM, Fouad OA. Synthesis and structure screening of nanostructured chromium oxide powders. J Alloys Compd 2009;482:302-7.

16. Fu XZ, Luo XX, Luo JL, Chuang KT, Sanger AR, Krzywicki A. Ethane dehydrogenation over nano- $\mathrm{Cr} \mathrm{O}$ anode catalyst in proton ceramic fuel cell reactors to co-produce ethylene and electricity. J Power Sources 2001;196(3):1036-41.

17. Kim DW, Shin SI, Lee JD, Oh SG. Preparation of chromia nanoparticles by precipitation-gelation reaction. Mater Lett 2004;58(12-13):1894-8.

18. Farzaneh F, Najafi M. Synthesis and characterization of $\mathrm{Cr}_{2} \mathrm{O}_{3}$ nanoparticles with triethanolamine in water under microwave irradiation. J Sci Islam Repub Iran 2011;22(4):329-33.

19. Karimian R, Piri F, Davarpanah SJ. Synthesis of zinc oxide and chromium (III) oxide nanoparticles with diverse physiological properties. J Appl Biotechnol Rep 2014;1(2):73-6.

20. Mougin J, Bihan TL, Lucazeau G. High-pressure study of $\mathrm{Cr}_{2} \mathrm{O}_{3}$ obtained by high-temperature oxidation by X-ray diffraction and Raman spectroscopy. J Phys Chem Solid 2001;62(3):553-63.

21. Ritu. Synthesis and characterization of chromium oxide nanoparticles. IOSR J Appl Chem 2015;8(3):5-11.

22. Negahdary M, Mohseni G, Fazilati M, Parsania S, Rahimi G, Rad S, et al. The antibacterial effect of cerium oxide nanoparticles on Staphylococcus aureus bacteria. Ann Biol Res 2012;3(7):3671-8.

23. Ramesh C, Mohan K, Senthil M, Ragunathan V. Antibacterial activity of $\mathrm{Cr}_{2} \mathrm{O}_{3}$ nanoparticles against $E$. coli; Reduction of chromate ions by Arachis hypogaea leaves. Arch Appl Sci Res 2012;4(4):1894-900.

24. Khatoon I, Vajpayee P, Singh G, Pandey AK, Dhawan A, Gupta KC, et al. Determination of internalization of chromium oxide nanoparticles in Escherichia coli by flow cytometry. J Biomed Nanotechnol 2011;7(1):168-9.

25. El-Ajaily MM, Abdlseed FA, Ben-Gweirif S. Preparation, characterization and antibacterial activity of some metal ion complexes. J Chem 2007;4(4):461-6.

26. Singh G, Vajpayee P, Khatoon I, Jyoti A, Dhawan A, Gupta KC, et al. Chromium oxide nano-particles induce stress in bacteria: Probing cell viability. J Biomed Nanotechnol 2011;7(1):166-7.

27. Rakesh, Ananda S, Madegowda NM. Sysnthesis of chromium (III) oxide nanoparticles by electrochemical method and Mukia maderaspatana plant extract, characterization, $\mathrm{KMnO}_{4}$ decomposition and antibacterial study. Mod Res Catal 2013;2:127-35.

28. Khalil HM. Influence of chromium nanoparticales on activity of Erwinia carotovora and Pseudomonas fluorescens. Int J Chem Environ Biol Sci (IJCEBS) 2013;1(1):492-505.

29. Hamzah BM, Senthil RK. Antibiotic sensitivity of gold and silver nanoparticles against enterococcal pathogens. Asian J Pharm Clin Res 2015;8(3):201-3

30. Wilson A, Prabukumar S, Sathishkumar G, Sivaramakrishnan S. Aspergillus flavus mediated silver nanoparticles synthesis and evaluation of its antimicrobial activity against different human pathogens. Int J Appl Pharm 2016;8(4):43-6.

31. Henderson MA. Photochemistry of methyl bromide on the $\alpha-\mathrm{Cr}_{2} \mathrm{O}_{3}$ surface. Surf Sci 2010;604(19):1800-7. 